\title{
Alkanediamide-Linked Bisbenzamidines Are Promising Antiparasitic Agents
}

\author{
Jean J. Vanden Eynde ${ }^{1}$, Annie Mayence ${ }^{1}$, Madhusoodanan Mottamal ${ }^{2,3}$, Cyrus J. Bacchi ${ }^{4}$, \\ Nigel Yarlett ${ }^{5}$, Marcel Kaiser ${ }^{6}$, Reto Brun ${ }^{6}$ and Tien L. Huang ${ }^{1,2, *}$ \\ 1 College of Pharmacy, Xavier University of Louisiana, New Orleans, LA 70125, USA; \\ jean-jacques.vandeneynde@ex.umons.ac.be (J.J.V.E.); annie.mayence@condorcet.be (A.M.) \\ 2 RCMI Cancer Research Center, Xavier University of Louisiana, New Orleans, LA 70125, USA; \\ mmottama@xula.edu \\ 3 Department of Chemistry, Xavier University of Louisiana, New Orleans, LA 70125, USA \\ 4 Haskins Laboratories and Department of Biological and Health Sciences, Pace University, 1 Pace Plaza, \\ New York, NY 10038, USA; cbacchi@pace.edu \\ 5 Haskins Laboratories and Department of Chemistry and Physical Sciences, Pace University, 1 Pace Plaza, \\ New York, NY 10038, USA; nyarlett@pace.edu \\ 6 Swiss Tropical and Public Health Institute, Socinstrasse 57, Basel CH-4002, Switzerland; \\ marcel.kaiser@unibas.ch (M.K.); reto.brun@unibas.ch (R.B.) \\ * Correspondence: thuang@xula.edu; Tel.: +1-504-520-7603; Fax: +1-504-520-7954
}

Academic Editor: Suzanne Peyrottes

Received: 11 February 2016; Accepted: 13 April 2016; Published: 19 April 2016

\begin{abstract}
A series of 15 alkanediamide-linked bisbenzamidines and related analogs was synthesized and tested in vitro against two Trypanosoma brucei (T.b.) subspecies: T.b. brucei and T.b. rhodesiense, Trypanosoma cruzi, Leishmania donovani and two Plasmodium falciparum subspecies: a chloroquine-sensitive strain (NF54) and a chloroquine-resistant strain (K1). The in vitro cytotoxicity was determined against rat myoblast cells (L6). Seven compounds (5, 6, 10, 11, 12, 14, 15) showed high potency against both strains of T. brucei and P. falciparum with the inhibitory concentrations for $50 \%\left(\mathrm{IC}_{50}\right)$ in the nanomolar range $\left(\mathrm{IC}_{50}=1-96 \mathrm{nM}\right)$. None of the tested derivatives was significantly active against T. cruzi or L. donovani. Three of the more potent compounds $(\mathbf{5}, \mathbf{6}, \mathbf{1 1})$ were evaluated in vivo in mice infected with the drug-sensitive (Lab 110 EATRO and KETRI 2002) or drug-resistant (KETRI 2538 and KETRI 1992) clinical isolates of T. brucei. Compounds 5 and 6 were highly effective in curing mice infected with the drug-sensitive strains, including a drug-resistant strain KETRI 2538, but were ineffective against KETRI 1992. Thermal melting of DNA and molecular modeling studies indicate AT-rich DNA sequences as possible binding sites for these compounds. Several of the tested compounds are suitable leads for the development of improved antiparasitic agents.
\end{abstract}

Keywords: antiparasitics; bisbenzamidines; DNA binding; Plasmodium falciparum; Trypanosoma brucei

\section{Introduction}

We previously reported on the promising anti-Pneumocystis activity of two key alkanediamide-linked bisbenzamidines when evaluated in an animal model of pneumocystosis [1,2]. Based on the results with the two lead compounds, the synthesis of an expanded series of alkanediamide-linked bisbenzamidines and the in vitro anti-Pneumocystis and anti-trypanosomal activities were reported [3]. The in vitro results showed excellent activity against drug-sensitive and -resistant isolates of Trypanosoma brucei with low cytotoxicity in the A549 human lung carcinoma cell line. The design strategy of replacing the strong electron-donating ether functions of the pentyldioxylinker in pentamidine with poor electron-donating amide functions in the lead compounds (5 and 6, Figure 1) resulted in highly potent antiprotozoal agents with greatly reduced 
cytotoxicity. In this study, we wish to report on the antiparasitic activity of the expanded series of alkanediamide-linked bisbenzamidines against several other parasitic protozoa such as T. cruzi, L. donovani, P. falciparum as well as their in vivo efficacy in several animal models of trypanosomiasis infected with drug-sensitive (Lab 110 EATRO and KETRI 2002) or -resistant (KETRI 2538 and 1992) clinical isolates [4] of T.b. rhodesiense.
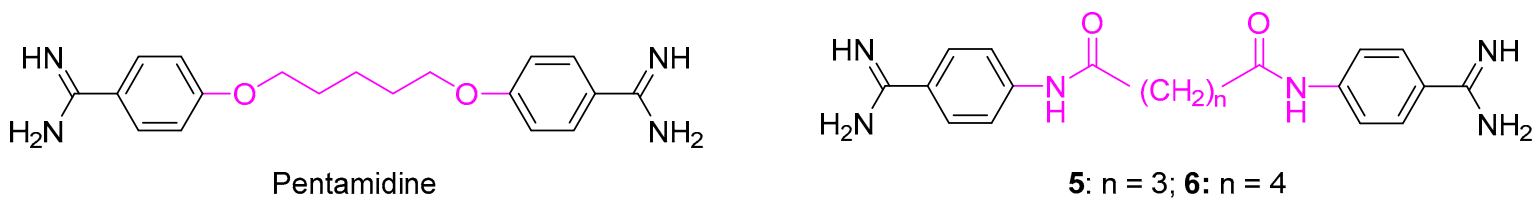

Figure 1. Chemical structures of pentamidine and lead compounds.

There is a great need for new antiparasitic agents with improved efficacy and low toxicity. Current chemotherapy is inadequate for many parasitic diseases because of limited efficacy, unacceptable side effects, and increasing occurrence of resistance. Development of an effective vaccine for these parasitic diseases have proven ineffective, therefore, chemotherapy with existing drugs is the only available therapeutic option. Parasitic diseases infect almost one sixth of the world population (>one billion people), with malaria being the most common. Besides its antimicrobial properties, the bisbenzamidines class of agents, represented by pentamidine, has demonstrated a wide range of biological properties [5] including anticancer, antidiabetic, antiviral and antiparasitic properties. However, pentamidine is clinically used only in the treatment of Pneumocystis jirovecii pneumonia, early stage human African trypanosomiasis and antimony-resistant leishmaniasis. The development of a novel prodrug from the bisbenzamidine class, parafuramidine maleate (DB289) against HAT and Pneumocystis pneumonia, was halted in a phase III sleeping sickness clinical trial because of nephrotoxicity in healthy volunteers [6]. Despite this setback, there is considerable interest in developing novel and safer bisbenzamidines [7] and several of these compounds are in various stages of drug development [8].

\section{Results and Discussion}

\subsection{Chemistry}

The syntheses of the targeted compounds are illustrated in Scheme 1. It is to be noted that the complete synthetic and structural characterization have been described for compounds 3-6 and 8 in the literature $[1,3,9]$ but not for the other compounds reported in this study. The appropriate diacid chlorides were reacted with aminobenzamidine or aminobenzonitrile or aminobenzamide to obtain the bisbenzamidines $(\mathbf{1}, \mathbf{2}, \mathbf{5 - 7}, \mathbf{1 0}-\mathbf{1 5})$, bisbenzonitrile (3) and bisbenzamides $(\mathbf{8}, \mathbf{9})$ in fair yields. The bisbenzamidoxime 4 is readily obtained by reacting 3 with hydroxylamine. Compound 4 is specifically designed to function as a prodrug with improved oral bioavailability by masking the highly basic amidine functions with the less basic amidoxime moieties. We recently demonstrated that the amidoxime moiety in 4 is readily metabolized to the amidine function following incubation in vitro with mouse liver microsomes [9]. 


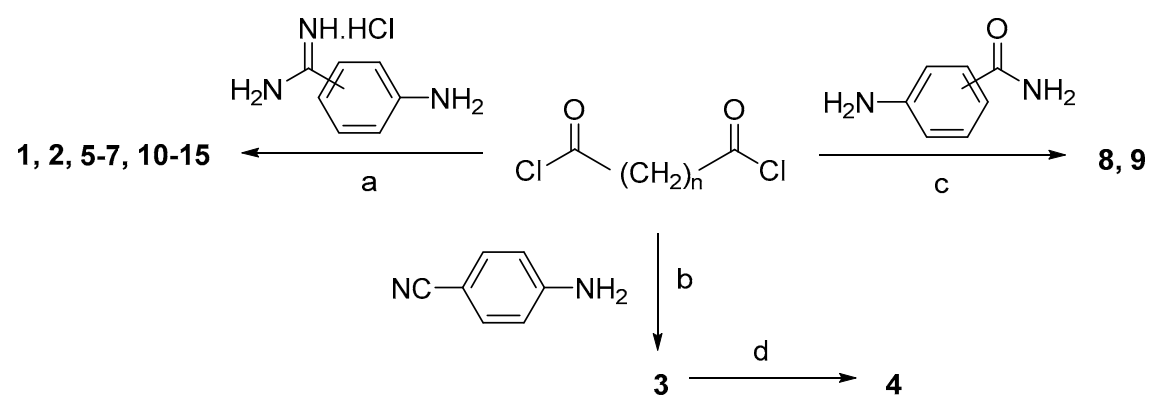

Scheme 1. General procedures for the synthesis of compounds 1-15. Reagents and conditions: (a) DMF, pyridine, reflux, 30 min-2 h; (b) and (c): Dioxane, room temp., stirred overnight; (d) Hydroxylamine, DMSO, $70{ }^{\circ} \mathrm{C}, 17 \mathrm{~h}$.

\subsection{Pharmacology}

The structure-activity relationship of 15 alkanediamide-linked bisbenzamidines (including analogs) and their antiparasitic activity were studied. Several of the bisbenzamidines were characterized with high potency against the two strains of T. brucei and P. falciparum (Table 1). Bisbenzamidines linked with the diamide moiety of the type Bza-NHCO- $\left(\mathrm{CH}_{2}\right)_{\mathrm{n}}-\mathrm{CONH}-\mathrm{Bza}$ where Bza = benzamidine, $n=3,4,5,6,8,10$ showed high potency against both strains of $T$. brucei and P. falciparum in the low nanomolar range $\left(\mathrm{IC}_{50}=1-96 \mathrm{nM}\right)$ irrespective of the length of the methylene chain. Compound 1 was also highly active ( $\mathrm{IC}_{50}=3-8 \mathrm{nM}$ ) against both strains of $P$. falciparum, but was inactive against the other parasitic protozoa. None of the tested derivatives was active against T. cruzi or L. donovani. The tested compounds exhibited low cytotoxicity against the non-carcinoma L6 rat skeletal myoblasts cell line.

The selectivity index of these compounds for T. brucei $\left(\mathrm{SI}_{T . b}\right)$ or P. falciparum $\left(\mathrm{SI}_{P . f}\right)$ are defined as the ratio of the $\mathrm{L} 6$ cells $\mathrm{IC}_{50}$ to the T. brucei or P. falciparum $\mathrm{IC}_{50}$ values. Based on this definition, the most selective compounds in this series against T. brucei was compound 6 with SI $>50,000$, whereas compounds $\mathbf{1}$ and $\mathbf{5}$ were the most selective against $P$. falciparum with SI $>33,000$. The selectivity indices for the reference compounds, pentamidine or chloroquine, could not be calculated since they were not tested in the L6 cells. The remarkable low cytotoxicity and high selectivity of some of the compounds, especially 5 and $\mathbf{6}$ when compared with pentamidine, were demonstrated earlier with the lung A549 [3] lung NCI-H460, CNS SF-268 and breast MCF7 carcinoma cell lines [10]. In vivo evaluation in the immunosuppressed mouse model of Pneumocystosis demonstrated that compound 5 was highly efficacious against the infection at $20 \mathrm{mg} / \mathrm{kg}$ and $40 \mathrm{mg} / \mathrm{kg}$, with $>1000$-fold reductions in burden, and resulted in improved survival curves versus those of pentamidine treated mice at the same doses [2]. The replacement of the dioxypentyl linker in pentamidine with the diamidealkyl linker resulted in compounds with reduced toxicity. This might be attributed to the lower lipophilicity (see Table 2) and different pathways of metabolism of these compounds since it has been suggested that the phenolic linkage in pentamidine might be involved in the toxicity of the compound [11]. Further characterization of the metabolites of our compounds would be needed to confirm this hypothesis. 
Table 1. In vitro antiparasitic and cytotoxic properties of alkanediamide-linked bisbenzamidines and analogs.

\begin{tabular}{|c|c|c|c|c|c|c|c|c|c|c|}
\hline \multirow{2}{*}{ Compd. } & \multirow{2}{*}{$\mathbf{n}$} & & & \multicolumn{7}{|c|}{$\mathrm{IC}_{50}(\mu \mathrm{M})^{\mathrm{a}}$} \\
\hline & & $A m=$ & $\ll_{\mathrm{NH}_{2}}^{\mathrm{NH}}$ & T.b. bruce $i^{\mathrm{b}}$ & T.b. rhod ${ }^{\mathrm{c}}$ & T. cruzi & L. donovani & P. falcipNF54 ${ }^{\mathrm{d}}$ & P. falcip $\mathrm{K} 1^{\mathrm{e}}$ & L6 Cells \\
\hline 1 & 1 & p-Am & p-Am & ND & ND & $>100$ & $>100$ & 0.008 & 0.003 & $>100$ \\
\hline 2 & 2 & $\mathrm{p}-\mathrm{Am}$ & $\mathrm{p}-\mathrm{Am}$ & 9.0 & 2.19 & $>100$ & $>100$ & ND & 0.29 & 28.0 \\
\hline 3 & 3 & $\mathrm{p}-\mathrm{CN}$ & $\mathrm{p}-\mathrm{CN}$ & 6.50 & 7.90 & $>100$ & $>100$ & ND & 44.8 & $>100$ \\
\hline 4 & 3 & $\mathrm{p}-\mathrm{C}(=\mathrm{NOH}) \mathrm{NH}_{2}$ & $\mathrm{p}-\mathrm{C}(=\mathrm{NOH}) \mathrm{NH}_{2}$ & 7.30 & 10.0 & $>100$ & $>100$ & ND & 3.16 & $>100$ \\
\hline 5 & 3 & $\mathrm{p}-\mathrm{Am}$ & $\mathrm{p}-\mathrm{Am}$ & 0.009 & 0.096 & $>100$ & $>100$ & 0.002 & 0.002 & 69.0 \\
\hline 6 & 4 & $\mathrm{p}-\mathrm{Am}$ & $\mathrm{p}-\mathrm{Am}$ & 0.003 & 0.002 & $>100$ & $>100$ & 0.004 & 0.018 & $>100$ \\
\hline 7 & 4 & m-Am & m-Am & 0.041 & 0.021 & $>100$ & $>100$ & ND & 0.38 & $>100$ \\
\hline 8 & 4 & $\mathrm{p}-\mathrm{CONH}_{2}$ & $\mathrm{p}-\mathrm{CONH}_{2}$ & 2.80 & 1.10 & $>100$ & $>100$ & ND & $>100$ & $>100$ \\
\hline 9 & 4 & $\mathrm{~m}-\mathrm{CONH}_{2}$ & $\mathrm{~m}-\mathrm{CONH}_{2}$ & NT & 1.97 & $>100$ & $>100$ & ND & $>100$ & 46.4 \\
\hline 10 & 4 & $\mathrm{p}-\mathrm{Am}$ & $\mathrm{m}-\mathrm{Am}$ & 0.012 & 0.007 & $>100$ & $>100$ & 0.015 & 0.004 & $>100$ \\
\hline 11 & 5 & p-Am & p-Am & 0.002 & 0.002 & $>100$ & $>100$ & 0.002 & 0.002 & 43.0 \\
\hline 12 & 6 & p-Am & p-Am & 0.003 & 0.001 & $>100$ & $>100$ & 0.002 & 0.006 & 38.4 \\
\hline 13 & 7 & p-Am & p-Am & 0.400 & 0.240 & 99.5 & 67.4 & 0.002 & 0.008 & 49.2 \\
\hline 14 & 8 & $\mathrm{p}-\mathrm{Am}$ & $\mathrm{p}-\mathrm{Am}$ & 0.002 & 0.004 & 76.4 & 68.5 & 0.014 & 0.012 & 78.6 \\
\hline Ref & & & & $0.002^{\mathrm{f}}$ & $0.002^{\mathrm{f}}$ & $1.13^{g}$ & $0.44^{\mathrm{h}}$ & $0.006^{\mathrm{i}}$ & $0.18^{\mathrm{i}}$ & $0.010^{j}$ \\
\hline
\end{tabular}


Table 2. Calculated physicochemical properties, Lipinski rule of 5 and lead likeness.

\begin{tabular}{|c|c|c|c|c|c|c|c|c|c|c|}
\hline Compd. & MolWt & $\log P$ & $\begin{array}{l}{ }^{a} \text { H-don } \\
\text { Count }\end{array}$ & $\begin{array}{c}\text { b H-acc } \\
\text { Count }\end{array}$ & ${ }^{c}$ Ring \# & $\log D$ & $\begin{array}{l}\mathrm{d} \text { Rot } \\
\text { Bonds }\end{array}$ & e PSA & $\begin{array}{c}\text { Lipinki } \\
\text { Rule of } 5\end{array}$ & $\begin{array}{c}\text { Lead } \\
\text { Likeness }\end{array}$ \\
\hline 1 & 338.37 & 0.38 & 6 & 6 & 2 & -4.44 & 6 & 157.94 & 3 of 4 & 4 of 6 \\
\hline 2 & 352.40 & 0.31 & 6 & 6 & 2 & -4.5 & 7 & 157.94 & 3 of 4 & 4 of 6 \\
\hline 3 & 332.36 & 2.63 & 2 & 4 & 2 & 2.63 & 6 & 105.78 & 4 of 4 & 6 of 6 \\
\hline 4 & 398.42 & 0.75 & 6 & 8 & 2 & 0.74 & 8 & 175.42 & 3 of 4 & 5 of 6 \\
\hline 5 & 366.42 & 0.76 & 6 & 6 & 2 & -4.06 & 8 & 157.94 & 3 of 4 & 4 of 6 \\
\hline 6 & 380.45 & 1.20 & 6 & 6 & 2 & -3.61 & 9 & 157.94 & 3 of 4 & 5 of 6 \\
\hline 7 & 380.45 & 1.20 & 6 & 6 & 2 & -3.6 & 9 & 157.94 & 3 of 4 & 5 of 6 \\
\hline 8 & 382.42 & 1.06 & 4 & 6 & 2 & 1.06 & 9 & 144.38 & 4 of 4 & 6 of 6 \\
\hline 9 & 382.42 & 1.06 & 4 & 4 & 2 & 1.06 & 9 & 144.38 & 4 of 4 & 6 of 6 \\
\hline 10 & 380.45 & 1.20 & 6 & 6 & 2 & -3.61 & 9 & 157.94 & 3 of 4 & 5 of 6 \\
\hline 11 & 394.48 & 1.64 & 6 & 6 & 2 & -3.17 & 10 & 157.94 & 3 of 4 & 5 of 6 \\
\hline 12 & 408.50 & 2.09 & 6 & 6 & 2 & -2.72 & 11 & 157.94 & 3 of 4 & 4 of 6 \\
\hline 13 & 422.53 & 2.53 & 6 & 6 & 2 & -2.28 & 12 & 157.94 & 3 of 4 & 4 of 6 \\
\hline 14 & 436.56 & 2.98 & 6 & 6 & 2 & -1.84 & 13 & 157.94 & 3 of 4 & 4 of 6 \\
\hline 15 & 466.61 & 3.87 & 6 & 6 & 2 & -0.95 & 15 & 157.94 & 3 of 4 & 4 of 6 \\
\hline $16^{f}$ & 340.42 & 2.32 & 4 & 6 & 2 & -2.50 & 10 & 118.20 & 4 of 4 & 6 of 6 \\
\hline
\end{tabular}

Because of the promising in vitro activities, several compounds $(5, \mathbf{6}, \mathbf{1 1})$ were selected for in vivo efficacy studies using mice infected with drug-susceptible (Lab 110 EATRO and KETRI 2002) and drug-resistant (KETRI 2538 and 1992) strains of T. brucei (Table 3). The compounds were administered via the intraperitoneal route at doses ranging from $1.0 \mathrm{mg} / \mathrm{kg} /$ day to $25.0 \mathrm{mg} / \mathrm{kg} /$ day for 3 days unless otherwise noted. Pentamidine was used as the reference compound. All three of the tested compounds were effective in curing mice infected with the Lab 110 EATRO or KETRI 2002 strains at several doses. Compound $\mathbf{1 1}$ was the most effective against these two strains since it also cured the mice at lower doses $(1.0$ or $2.5 \mathrm{mg} / \mathrm{kg}$ ). Two of the tested compounds, namely 5 and $\mathbf{6}$, were highly efficacious in curing mice infected with the drug-resistant KETRI 2538 clinical isolate at several doses. However, the bisbenzamidines including pentamidine were ineffective in curing mice infected with the drug-resistant KETRI 1992 isolate, although the tested compound 5 prolonged the mean survival days of the treated animals to 25 days at the $25 \mathrm{mg} / \mathrm{kg}$ dose.

The in vivo results reported here as well as the earlier results with pneumocystosis [2] indicate that several of the bisbenzamidines reported here are suitable leads for further optimization to develop orally active prodrugs. These compounds generally differ from pentamidine in having lower lipophilicity, greater $\mathrm{H}$-bond donor capability and polar surface area (Table 2). The bisamidine moieties have similar calculated basicity (pKa 10.68) when compared to pentamidine (pKa 10.94). Several of them have "lead-like" characteristics based on physicochemical properties. Therefore, modifying the leads into prodrugs with greater oral bioavailability would be a rational approach to develop more effective antiparasitic agents. In fact, we have already reported our initial attempts in this approach [9] by selecting compound $\mathbf{5}$ as a lead in which the amidine functions were masked with less basic and more lipophilic moieties that can readily be biotransformed into the active amidine functions. Further in vitro metabolism study of these potential prodrugs is in progress. 
Table 3. In vivo trypanocidal activity of selected compounds in mice ${ }^{\text {a }}$.

\begin{tabular}{|c|c|c|c|c|}
\hline Clinical Isolate & Compd. & $\begin{array}{c}\text { Dosage } \\
\text { (mg/kg/Day) }\end{array}$ & $\begin{array}{l}\text { Mean Survival } \\
\text { (Days) }\end{array}$ & $\begin{array}{c}\text { No. of Mice } \\
\text { Cured/Total (\%) }\end{array}$ \\
\hline \multirow{13}{*}{ Lab 110 EATRO $^{b}$} & None & - & 5.0 & $0 / 3$ \\
\hline & Pentamidine & $1.0,2.5,5,10$ & $>30$ & $5 / 5(100)^{c}$ \\
\hline & \multirow{5}{*}{5} & 1.0 & 6.0 & $0 / 3$ \\
\hline & & 2.5 & 11.3 & $0 / 3$ \\
\hline & & 5 & 10 & $2 / 3(66)$ \\
\hline & & 10 & $>30$ & $3 / 3(100)$ \\
\hline & & 15 & $>30$ & $3 / 3(100)$ \\
\hline & \multirow{5}{*}{6} & 1.0 & 6.7 & $0 / 3$ \\
\hline & & 2.5 & 10.0 & $0 / 3$ \\
\hline & & 5 & $>30$ & $3 / 3(100)$ \\
\hline & & 10 & $>30$ & $3 / 3(100)$ \\
\hline & & 15 & $>30$ & $3 / 3(100)$ \\
\hline & 11 & $1.0,2.5,5,10$ & $>30$ & $3 / 3(100)^{c}$ \\
\hline \multirow{5}{*}{ KETRI $2002^{b}$} & None & - & 9.0 & $0 / 3$ \\
\hline & Pentamidine & $1.0,5,10$ & $>30$ & $5 / 5(100)^{c}$ \\
\hline & 5 & $10,15,25$ & $>30$ & $3 / 3(100)^{c}$ \\
\hline & 6 & $10,15,25$ & $>30$ & $3 / 3(100)^{c}$ \\
\hline & 11 & $1.0,2.5,5,10$ & $>30$ & $3 / 3(100)^{c}$ \\
\hline \multirow{4}{*}{ KETRI $2538^{b}$} & None & - & 4.3 & $0 / 3$ \\
\hline & Pentamidine & $1.0,5,10$ & $>30$ & $5 / 5(100)^{c}$ \\
\hline & 5 & $10,15,25$ & $>30$ & $3 / 3(100)^{c}$ \\
\hline & 6 & $5,10,15$ & $>30$ & $3 / 3(100)^{c}$ \\
\hline \multirow{7}{*}{ KETRI $1992^{\text {b }}$} & None & - & 7.4 & $0 / 5$ \\
\hline & \multirow{3}{*}{ Pentamidine } & 1 & 12.6 & $0 / 3$ \\
\hline & & 5 & 17.0 & $0 / 3$ \\
\hline & & 10 & 22.2 & $0 / 3$ \\
\hline & \multirow{3}{*}{5} & 10 & 17.5 & $0 / 3$ \\
\hline & & 15 & 14.5 & $0 / 3$ \\
\hline & & 25 & 25 & $0 / 3$ \\
\hline
\end{tabular}

a In vivo efficacy of compounds given via i.p route $v$ s. several clinical isolates of T. brucei. Mice were infected with 250,000 parasites and dosing commenced $24 \mathrm{~h}$ post infection. Mice were separated into groups of three and injected i.p once a day for 3 days unless otherwise noted. Infected untreated controls were used for each experiment. Mice were considered cured if surviving more than 30 days beyond death of the last control without parasites in tail vein blood smears. Mean survival (in days) of animals dying of trypanosomiasis is exclusive of cured animals. ${ }^{b}$ Trypanosome strains. T.b. brucei Lab 110 EATRO strain is susceptible to standard trypanocides including the diamidines. The following are clinical isolates of T.b. rhodesiense: KETRI 243, 2002, 2538 and 1992. Strain 2002 is susceptible to standard trypanocides including the diamidines. Strains refractory to DFMO are KETRI 243 and 2538. Strains refractory to arsenical drugs are KETRI 243, 1992 and 2538. Strains refractory to diamidines are KETRI 243 and 1992 (see [4] for details). ${ }^{c}$ All doses cured. Groups of 3 or 5 animals used for all doses.

Bisbenzamidines such as pentamidine, propamidine and furamidine have been recognized as promising antimicrobial agents against bacteria, protozoa, fungi and amoeba [7]. This class of compounds has demonstrated excellent activity against Pneumocystis, Trypanosoma spp., Leishmania spp., and Plasmodium spp. $[2,3,14,15]$. These compounds have been proposed to act by initially binding to DNA at AT-rich sites followed by inhibition of one or more of several DNA dependent enzymes (e.g., topoisomerases and nucleases) or by direct inhibition of the transcription process [16,17]. In kinetoplastid parasites such as African trypanosomes, the bisbenzamidines are postulated to be taken up by transporters and concentrate in the mitochondrion leading to destruction of the kinetoplast 
DNA [7]. In the case of P. falciparum, the nuclear DNA has been implicated as the bioreceptor target [18]. However, other possible modes of action cannot be ruled out. These include the binding of these compounds to ferriprotoporphyrin IX and inhibiting the formation of hemozoin $[15,19,20]$, disruption of polyamine metabolism [21], and interactions with a host of non-conventional biomolecular targets [5]. These observations suggest that dicationic diamidines are pleotropic compounds that are capable of interacting with multiple targets.

In addition to the determination of the potency of the synthesized compounds against different strains of cell lines (Table 1), thermal melting experiments of these compounds were also conducted with poly(dA-dT) and calf thymus DNA (Table S1, supplementary file). In general, the $\Delta \mathrm{T}_{\mathrm{m}}$ values are higher for poly $(\mathrm{dA}-\mathrm{dT})$ and a correlation was obtained between the $\Delta \mathrm{T}_{\mathrm{m}}$ of poly $(\mathrm{dA}-\mathrm{dT})$ and the $\mathrm{pIC}_{50}$ values of these compounds in T.b. brucei $(r=0.73)$, T.b. rhodesiense $(r=0.79)$ (see Figure S1A,B, supplementary file) and $P$. falciparum $\mathrm{K} 1(r=0.67)$ (Figure S1C, supplementary file). The weaker binding to DNA (lower $\Delta \mathrm{T}_{\mathrm{m}}$ values) compared to pentamidine might be attributed to the lower lipophilicity and higher PSA properties of these compounds since they would be expected to bind less favorably in the less polar environment of the minor grove of DNA as was reported for the aza-analogues of furamidine [11]. Our results suggest that the antiparasitic activities of the benzamidine analogs against T.b. brucei, T.b. rhodesiense and P. falciparum $\mathrm{K} 1$ are associated with their ability to bind to AT rich oligomers, as reported in the literature [7,20,22]. However, it should be noted that compound 5 and several bisbenzamidines with various linkers were shown to interfere with hemozoin formation at micromolar concentrations in ex vivo experiments [15]. Therefore, ability of these compounds to act at other potential targets cannot be ruled out.

\subsection{Molecular Modeling Studies}

In order to examine how these compounds bind to the minor groove of AT-rich DNA duplex and their preferred affinities for specific AT-rich binding sites, we have done docking studies as described in the supplementary section. Docking scores and correlation coefficients $\left(r\right.$ and $p$ ) between the pIC $\mathrm{I}_{50}$ and dockings scores are tabulated in Tables S1 and S2 (supplementary file). Correlation data indicates that our compounds have high preference for binding to the minor groove of a single G or GC inserted AT-rich DNA duplexes. In the active compound 15, the terminal amidines displayed three H-bonds and the linker diamide formed one H-bond with the nucleotides of DNA. The detailed binding interactions of compounds 11 and 15 with the DNA can be found in the supplementary section (Figure S2). In the crystal structure of pentamidine in complex with AT-rich DNA, one of the terminal amidines formed one H-bond with $\mathrm{N} 3$ of A5 and a close contact to $\mathrm{O}^{\prime}$ of A6, and the other terminal amidine formed one H-bond with N3 of A17, a close contact to $4^{\prime}$ of A18 and one water mediated contact to O4 $4^{\prime}$ of G10 [23]. While it may not be a direct comparison, as in the crystal structure our model also exhibited at least two H-bond interactions between the terminal amidines and the nucleotide. Thus, the observed hydrogen bond interactions and the appropriate curvature of the compounds to match the convex shape of the DNA minor groove may be responsible for the higher affinity of active compounds. This study shows that our compounds better bind to G or GC inserted AT-rich sites. While these models provide a tool to study the trend in binding of our compounds to different oligomers, for an exact representation of the drug-DNA interactions X-ray or NMR structures are more desirable.

\section{Experimental Section}

\subsection{Chemistry}

${ }^{1} \mathrm{H}-\mathrm{NMR}$ spectra were obtained using a Varian Inova instrument $(500 \mathrm{MHz}$ ) (Agilent Technologies, Santa Clara, CA, USA), and chemical shifts $(\delta)$ are given in ppm using TMS as internal reference and coupling constants $(J)$ in Hz. IR spectra were recorded on a Perkin-Elmer Spectrum One spectrometer (PerkinElmer, Waltham, MA, USA) operating in the diffuse reflectance mode. High resolution mass spectra (HRMS) were recorded on an Orbitrap mass spectrometer (Thermo Fisher Scientific, Waltham, 
MA, USA) with electrospray ionization (ESI). Solvents and reagents were commercially available (Aldrich, St. Louis, MO, USA; Fisher Scientific, Pittsburg, PA, USA) and were used without further purification. Elemental analysis was carried out by $\mathrm{M}-\mathrm{H}-\mathrm{W}$ laboratories, Phoenix, AZ. Analysis of C, $\mathrm{H}, \mathrm{N}$ were within $\pm 0.4 \%$ of theoretical values. Compounds 3 [3], 4 [9], 5 [3], 6 [1] and 8 [3] have been described in the literature.

\section{General Synthesis of Bisbenzamidines 1, 2, 7, 10-15}

A mixture of 4 -aminobenzamidine and/or 3-aminobenzamidine $(10 \mathrm{mmol})$, pyridine $(8 \mathrm{~mL}$, $100 \mathrm{mmol})$, appropriate diacid chloride ( $5 \mathrm{mmol})$, in $N, N$-dimethyl formamide $(40 \mathrm{~mL})$ was refluxed for 30-120 min. The resultant precipitate was filtered and washed with the appropriate solvents.

$N, N^{\prime}$-bis[4-(aminoiminomethyl)phenyl] ethane-1,2-dicarboxamide (1). The product was successively washed with water and acetone to yield 10\% solid, m.p. $>300{ }^{\circ} \mathrm{C}$; IR:3130, 1674, 1611, 1514, $1412 \mathrm{~cm}^{-1}$; ${ }^{1} \mathrm{H}-\mathrm{NMR}$ : $\left(\mathrm{DMSO}_{-} \mathrm{d}_{6}\right) \delta 11.1(\mathrm{~s}, \mathrm{br}, 2 \mathrm{H}) ; 9.2(\mathrm{~s}, \mathrm{br}, 8 \mathrm{H}) ; 8.0(\mathrm{~d}, 4 \mathrm{H}, J=9 \mathrm{~Hz}), 7.9(\mathrm{~d}, 4 \mathrm{H}, J=9 \mathrm{~Hz}) \mathrm{ppm}$. Anal. Calcd. for $\mathrm{C}_{16} \mathrm{H}_{16} \mathrm{~N}_{6} \mathrm{O}_{2} \cdot 2 \mathrm{HCl} \cdot 1.5 \mathrm{H}_{2} \mathrm{O}$ (424.28): C, 45.29; H, 4.98; N, 19.80. Found: C, 45.55; H, 5.12; N, 19.84 .

$N, N^{\prime}$-bis[4-(aminoiminomethyl)phenyl] butane-1,4-dicarboxamide (2). The product was successively washed with ethanol and ether to yield 40\% solid, m.p. > $300{ }^{\circ} \mathrm{C}$; IR:3030, 1669, 1602, 1541, $1415 \mathrm{~cm}^{-1}$; ${ }^{1} \mathrm{H}-\mathrm{NMR}:\left(\mathrm{DMSO}-\mathrm{d}_{6}\right) \delta 10.5(\mathrm{~s}, 2 \mathrm{H}) ; 9.2(\mathrm{~s}, 4 \mathrm{H}) ; 8.8(\mathrm{~s}, 4 \mathrm{H}) ; 7.8(\mathrm{~m}, 8 \mathrm{H}) ; 2.7$ (s, br, 4H) ppm. Anal. Calcd. for $\mathrm{C}_{18} \mathrm{H}_{20} \mathrm{~N}_{6} \mathrm{O}_{2} \cdot 2 \mathrm{HCl}$ (424.28): C, 50.83; H, 5.21; N, 19.76. Found: C, 50.77; H, 5.44; N, 19.58 .

$N, N^{\prime}$-bis[3-(aminoiminomethyl)phenyl] hexane-1,6-dicarboxamide (7). The product was washed twice with acetone to yield 57\% solid, m.p. $>300{ }^{\circ} \mathrm{C}$; IR:3054; 1668; 1564; 1482;1411; $1314 \mathrm{~cm}^{-1}$; ${ }^{1} \mathrm{H}-\mathrm{NMR}:\left(\mathrm{DMSO}-\mathrm{d}_{6}\right) \delta 10.5(\mathrm{~s}, 2 \mathrm{H}) ; 9.3(\mathrm{~s}, 4 \mathrm{H}) ; 9.1(\mathrm{~s}, 4 \mathrm{H}) ; 8.1(\mathrm{~s}, 2 \mathrm{H}) ; 7.8(\mathrm{~d}, 2 \mathrm{H}) ; 7.5(\mathrm{t}, 2 \mathrm{H}) ; 7.3$ $(\mathrm{d}, 2 \mathrm{H}) ; 2.4$ (t br, $4 \mathrm{H}) ; 1.7$ ( $\mathrm{t} \mathrm{br}, 4 \mathrm{H})$ ppm. Anal. Calcd. for $\mathrm{C}_{20} \mathrm{H}_{24} \mathrm{~N}_{6} \mathrm{O}_{2} \cdot 2 \mathrm{HCl}$ (453.37): C, 52.98; $\mathrm{H}, 5.78$; $\mathrm{N}, 18.54$. Found: C, 52.74; H, 5.99; N, 18.45 .

N-[3-(aminoiminomethyl)phenyl] $N^{\prime}$-[4-(aminoimino methyl)phenyl] hexane-1,6-dicarboxamide (10). Oily liquid, \% yield unknown. IR:3086; 1667; 1601; 1481; 1315; $1264 \mathrm{~cm}^{-1} ;{ }^{1} \mathrm{H}-\mathrm{NMR}:\left(\mathrm{DMSO}-\mathrm{d}_{6}\right) \delta 10.7(\mathrm{~d}$, $1 \mathrm{H}) ; 10.5(\mathrm{~d}, 1 \mathrm{H}) ; 9.4(\mathrm{~s}, 2 \mathrm{H}) ; 9.2(\mathrm{~s}, 2 \mathrm{H}) ; 9.1(\mathrm{~s}, 4 \mathrm{H}) ; 9.0(\mathrm{~s}, 4 \mathrm{H}) ; 8.2(\mathrm{~s}, 1 \mathrm{H}) ; 7.8(\mathrm{~m}, 5 \mathrm{H}) ; 7.5(\mathrm{t}, 1 \mathrm{H}) ; 7.4(\mathrm{~d}$, $1 \mathrm{H}) ; 2.4$ (m br, $4 \mathrm{H}) ; 1.6$ (m br, $4 \mathrm{H})$ ppm. HRMS: found 381.2057, calcd. 381.2039 for $\mathrm{C}_{20} \mathrm{H}_{24} \mathrm{~N}_{6} \mathrm{O}_{2}$.

$N, N^{\prime}$-bis[4-(aminoiminomethyl)phenyl] heptane-1,7-dicarboxamide (11). The product was successively washed with ethanol and ether to yield $45 \%$ solid, m.p. $>300{ }^{\circ} \mathrm{C}$; IR:3117, 1675, 1616, 1541, $1496 \mathrm{~cm}^{-1}$; ${ }^{1} \mathrm{H}-\mathrm{NMR}:\left(\mathrm{DMSO}_{6}\right) \delta 10.5(\mathrm{~s}, 2 \mathrm{H}) ; 9.2(\mathrm{~s}, 4 \mathrm{H}) ; 8.9(\mathrm{~s}, 4 \mathrm{H}) ; 7.8(\mathrm{~m}, 8 \mathrm{H}) ; 2.3(\mathrm{t}, 4 \mathrm{H}, \mathrm{J}=7 \mathrm{~Hz}) ; 1.6(\mathrm{q}, 4 \mathrm{H}$, $J=7 \mathrm{~Hz}) ; 1.3(\mathrm{q}, 2 \mathrm{H}, J=7 \mathrm{~Hz})$ ppm. Anal. Calcd. for $\left.\mathrm{C}_{21} \mathrm{H}_{30} \mathrm{~N}_{6} \mathrm{O}_{2} \cdot 2 \mathrm{HCl} .0 .2 \mathrm{H}_{2} \mathrm{O}\right)(503.42): \mathrm{C}, 50.10 ; \mathrm{H}$, 6.40; N, 16.69. Found: C, 50.38; H, 6.03; N, 16.51 .

N,N'-bis[4-(aminoiminomethyl)phenyl] octane-1,8-dicarboxamide (12). The product was successively washed with water, ethanol and ether to yield 10\% solid, m.p. > $300{ }^{\circ} \mathrm{C}$; IR:3063, 1674, 1609, 1541, 1338, $1308 \mathrm{~cm}^{-1}$; ${ }^{1} \mathrm{H}-\mathrm{NMR}:\left(\mathrm{DMSO}_{6}\right) \delta 10.5(\mathrm{~s}, 2 \mathrm{H}) ; 9.2(\mathrm{~s}, 4 \mathrm{H}) ; 8.9(\mathrm{~s}, 4 \mathrm{H}) ; 7.8(\mathrm{~m}, 8 \mathrm{H}) ; 2.3(\mathrm{t}, 4 \mathrm{H}, \mathrm{J}=7 \mathrm{~Hz})$; $1.6(\mathrm{~m}, \mathrm{br}, 4 \mathrm{H}) ; 1.3(\mathrm{~m}, \mathrm{br}, 4 \mathrm{H})$ ppm. Anal. Calcd. for $\left.\mathrm{C}_{22} \mathrm{H}_{28} \mathrm{~N}_{6} \mathrm{O}_{2} \cdot 2 \mathrm{HCl}\right)(481.42): \mathrm{C}, 54.89 ; \mathrm{H}, 6.28 ; \mathrm{N}$, 17.46. Found: C, 55.12; H, 6.25; N, 17.28.

$N, N^{\prime}$-bis[4-(aminoiminomethyl)phenyl] nonane-1,9-dicarboxamide (13). After refluxing for $2 \mathrm{~h}$, the cooled solution was poured into acetone $(100 \mathrm{~mL})$. The product was successively washed with acetone and water to yield 50\% solid, m.p. > $300{ }^{\circ} \mathrm{C}$; IR:2935, 1696, 1674, 1541, $1330 \mathrm{~cm}^{-1} ;{ }^{1} \mathrm{H}-\mathrm{NMR}:\left(\mathrm{DMSO}-\mathrm{d}_{6}\right)$ $\delta 10.4$ (s, 2H); 9.3 (s, br, 8H); $7.8(\mathrm{~m}, 8 \mathrm{H}) ; 2.3(\mathrm{t}, 4 \mathrm{H}, J=7 \mathrm{~Hz}) ; 1.6(\mathrm{q}, \mathrm{br}, 4 \mathrm{H}) ; 1.3$ (q, br, 6H, J = $7 \mathrm{~Hz}) \mathrm{ppm}$. Anal. Calcd. for $\left.\mathrm{C}_{23} \mathrm{H}_{32} \mathrm{~N}_{6} \mathrm{O}_{2} \cdot 2 \mathrm{HCl} \cdot 0.5 \mathrm{C}_{2} \mathrm{H}_{5} \mathrm{OH}\right)$ (518.48): C, 55.60; H, 6.80; N, 16.21. Found: C, 55.98; $\mathrm{H}, 6.61 ; \mathrm{N}, 15.96$.

$N, N^{\prime}$-bis[4-(aminoiminomethyl)phenyl] decane-1,10-dicarboxamide (14). After refluxing for $2 \mathrm{~h}$, thecooled solution was poured into acetone $(100 \mathrm{~mL})$. The product was successively washed with acetone and water to yield 50\% solid, m.p. $>265{ }^{\circ} \mathrm{C}$ decomposed; IR:2931, 1667, 1599, 1559, $1487 \mathrm{~cm}^{-1}$; 
${ }^{1} \mathrm{H}-\mathrm{NMR}:\left(\mathrm{DMSO}-\mathrm{d}_{6}\right) \delta 10.4$ (s, 2H); 9.1 (s, br, 8H); $7.8(\mathrm{~m}, 8 \mathrm{H}) ; 2.4$ (t, 4H, J = $\left.7 \mathrm{~Hz}\right) ; 1.6(\mathrm{br} \mathrm{m}, 4 \mathrm{H}) ; 1.3$ (br m, $8 \mathrm{H}, J=7 \mathrm{~Hz}$ ) ppm. HRMS: found 437.2672 , calcd. 437.2665 for $\mathrm{C}_{24} \mathrm{H}_{32} \mathrm{~N}_{6} \mathrm{O}_{2}$.

$N, N^{\prime}$-bis[4-(aminoiminomethyl)phenyl] dodecane-1,12-dicarboxamide (15). The product was successively washed with water, ethanol and ether to yield $35 \%$ solid, m.p. $>300{ }^{\circ} \mathrm{C}$; IR:3093, 1669, 1602, 1541, $1411 \mathrm{~cm}^{-1} ;{ }^{1} \mathrm{H}-\mathrm{NMR}:\left(\mathrm{DMSO}_{6}\right) \delta 10.4(\mathrm{~s}, 2 \mathrm{H}) ; 9.2(\mathrm{~s}, 4 \mathrm{H}) ; 8.9(\mathrm{~s}, 4 \mathrm{H}) ; 7.8(\mathrm{~m}, 8 \mathrm{H}) ; 2.3(\mathrm{t}, 4 \mathrm{H}, J=8 \mathrm{~Hz})$; $1.6(\mathrm{q}, \mathrm{br}, 4 \mathrm{H}) ; 1.3(\mathrm{~m}, \mathrm{br}, 12 \mathrm{H})$ ppm. HRMS: found 465.2985 , calcd. 465.2978 for $\mathrm{C}_{26} \mathrm{H}_{36} \mathrm{~N}_{6} \mathrm{O}_{2}$.

\subsection{Biology}

\subsubsection{In Vitro Antiparasitic Activity}

The two clinical isolates of T. brucei used for the in vitro study were T. b. brucei Lab 110 EATRO (pentamidine-sensitive) and T. $b$. rhodesiense KETRi 243 (melarsoprol, pentamidine- and diminazene diaceturate-resistant) [14]. The in vitro assays with the two isolates of T. brucei were conducted according to previously described procedures [14]. The anti-T. cruzi activity was determined using intracellular amastigote forms of T. cruzi Tulahuen strain C2C4 in rat skeletal myoblasts (L6 cells) as described previously [24]. The anti-L. donovani activity was determined using the amastigotes of L. donovani strain MHOM-ET-67/L82 as described previously [24]. The anti-plasmodial activity against the two strains of P. falciparum NF54 (chloroquine-sensitive) and K1 (chloroquine-resistant) were determined using the erythrocytic stage of P. falciparum as described previously [24]. The cytotoxicity assays against rat skeletal myoblast L6-cells were performed as described previously [24].

\subsubsection{In Vivo Anti-Trypanosomal Activity in Mice}

The in vivo studies were conducted according to the procedures described previously $[4,14]$.

\subsubsection{DNA Binding Affinity Measurements}

The DNA binding affinity of the tested compounds was determined by measuring the change in mid-point of the thermal denaturation curves for a 1:5 compound to DNA base pair ratio as described previously [15]. Each $\mathrm{T}_{\mathrm{m}}$ value reported in Table S1 (supplementary file) represents the mean of at least two experimental determinations.

\subsection{Molecular Modeling Studies}

We used Surflex-Dock to study the DNA binding affinities of 16 bisbenzamidine compounds to the minor groove of AT-rich sites and an AT absent site. Computational details are described in supplementary section.

\section{Conclusions}

This study reports on the synthesis of a series of alkanediamide-linked bisbenzamidines (and analogs) and their in vitro and in vivo evaluation as potential antiparasitic agents. Potential cytotoxicity of the compounds in a mammalian cell line, as well as their interactions with DNA via thermal denaturation and molecular modeling studies, have been determined. Seven of the compounds $(5,6$, 10, 11, 12, 14, 15) were highly potent $\left(\mathrm{IC}_{50}=1-96 \mathrm{nM}\right)$ against drug-sensitive as well as drug-resistant cell lines of $T$. brucei and P. falciparum. Three compounds $(5,6,11)$ were highly effective in curing mice infected with the drug-sensitive strains (Lab 110 EATRO and KETRI 2002) of T. brucei, whereas 5 and 6 were also efficacious in curing mice infected with the drug-resistant KETRI 2538 clinical isolate. Thermal denaturation studies with DNA showed that these compounds have stronger binding to poly(dA-dT) versus calf thymus DNA and a good correlation was observed between the $\Delta \mathrm{T}_{\mathrm{m}}$ of poly $(\mathrm{dA}-\mathrm{dT})$ and the antiparasitic activity of these compounds against T. brucei and P. falciparum. Molecular modeling studies indicated that these compounds exhibited high preference for binding to 
the minor groove of a single G or GC inserted AT-rich (AAAGTTT or AAAGCTTT) DNA duplexes and they correlated well with the $\mathrm{pIC}_{50}$ values of the compounds against T. brucei and P. falciparum.

Supplementary Materials: The following are available online at http://www.mdpi.com/1424-8247/9/2/20/s1, Figure S1: Correlation between the experimental $\mathrm{pIC}_{50}$ in different cell lines and the $\Delta \mathrm{T}_{\mathrm{m}}$ with poly $(\mathrm{dA}-\mathrm{dT})$, Figure S2: Detailed views from the minor groove of the hydrogen bond interactions between compounds 11 and 15 and the central -AAAGTTT- sites of 5'-d(CCAAAGTTTGC)-3' duplex, Table S1: Docking of alkanediamide-linked bisbenzamidines and analogs to various DNA duplexes with specific central sequences, in vitro antiparasitic properties $\left(\mathrm{pIC}_{50}\right)$ and thermal melting data $\left(\Delta \mathrm{T}_{\mathrm{m}}\right)$ of tested analogs with poly $(\mathrm{dA}-\mathrm{dT})$ and CT-DNA, Table S2: Pearson's correlation $(r)$ between the experimental $\mathrm{pIC}_{50}$ values of three cell lines or $\Delta \mathrm{T}_{\mathrm{m}}$ of poly $(\mathrm{dA}-\mathrm{dT})$ and the docking scores for different central minor groove of sequences. Details of molecular modeling studies.

Acknowledgments: The work described in this manuscript has been funded in part by the (NIMHD-NIH) under grant number 2G12MD007595.

Author Contributions: J.J.V.E. and T.L.H. conceived and designed the study; J.J.V.E. and A.M. synthesized the compounds; C.B., N.Y., M.K., and R.B. performed the in vitro studies; C.B. and N.Y. performed the in vivo studies; M.M. performed the molecular modeling studies; J.J.V.E., M.M. and T.L.H. wrote the manuscript.

Conflicts of Interest: The authors declare no conflict of interest.

\section{References}

1. Vanden Eynde, J.J.; Mayence, A.; Huang, T.L.; Collins, M.S.; Rebholz, S.; Walzer, P.D.; Cushion, M.T. Novel bisbenzamidines as potential drug candidates for the treatment of Pneumocystis carinii pneumonia. Bioorg. Med. Chem. Lett. 2004, 14, 4545-4548. [CrossRef] [PubMed]

2. Cushion, M.T.; Walzer, P.D.; Ashbaugh, A.; Rebholz, S.; Brubaker, R.; Vanden Eynde, J.J.; Mayence, A.; Huang, T.L. In vitro selection and in vivo efficacy of piperazine- and alkanediamide-linked bisbenzamidines against Pneumocystis pneumonia in mice. Antimicrob. Agents Chemother. 2006, 50, 2337-2343. [CrossRef] [PubMed]

3. Huang, T.L.; Vanden Eynde, J.J.; Mayence, A.; Collins, M.S.; Cushion, M.T.; Rattendi, D.; Londono, I.; Mazumder, L.; Bacchi, C.J.; Yarlett, N. Synthesis and SAR of alkanediamide-linked bisbenzamidines with antitrypanosomal and anti-Pneumocystis activity. Bioorg. Med. Chem. Lett. 2009, 19, 5884-5886. [CrossRef] [PubMed]

4. Bacchi, C.J.; Nathan, H.C.; Livingston, T.; Valladares, G.; Saric, M.; Sayer, P.D.; Njogu, A.R.; Clarkson, A.B., Jr. Differential susceptibility to DL- $\alpha$-difluoromethylornithine in clinical isolates of Trypanosoma brucei rhodesiense. Antimicrob. Agents Chemother. 1990, 34, 1183-1188. [CrossRef] [PubMed]

5. Huang, T.L.; Mayence, A.; Vanden Eynde, J.J. Some non-conventional biomolecular targets for diamidines. A short survey. Bioorg. Med. Chem. 2014, 22, 1983-1992. [CrossRef] [PubMed]

6. Paine, M.F.; Wang, M.Z.; Generaux, C.N.; Boykin, D.W.; Wilson, W.D.; De Koning, H.P.; Olson, C.A.; Pohlig, G.; Burri, C.; Brun, R.; et al. Diamidines for human African trypanosomiasis. Curr. Opin. Investig. Drugs 2010, 11, 876-883. [PubMed]

7. Soeiro, M.N.; Werbovetz, K.; Boykin, D.W.; Wilson, W.D.; Wang, M.Z.; Hemphill, A. Novel amidines and analogues as promising agents against intracellular parasites: A systematic review. Parasitology 2013, 140, 929-951. [CrossRef] [PubMed]

8. Thuita, J.K.; Wolf, K.K.; Murilla, G.A.; Bridges, A.S.; Boykin, D.W.; Mutuku, J.N.; Liu, Q.; Jones, S.K.; Gem, C.O.; Ching, S.; et al. Chemotherapy of second stage human African trypanosomiasis: Comparison between the parenteral diamidine DB829 and its oral prodrug DB868 in vervet monkeys. PLoS Negl. Trop. Dis. 2015, 9, e0003409. [CrossRef] [PubMed]

9. Kode, N.R.; Vanden Eynde, J.J.; Mayence, A.; Wang, G.; Huang, T.L. Design and synthesis of $N^{1}, N^{5}$-bis[4-(5-alkyl-1,2,4-oxadiazol-3-yl)phenyl]glutaramides as potential antifungal prodrugs. Molecules 2013, 18, 11250-11263. [CrossRef] [PubMed]

10. Eynde, J.J.V.; Mayence, A.; Johnson, M.T.; Huang, T.L.; Collins, M.S.; Rebholz, S.; Walzer, P.D.; Cushion, M.T.; Donkor, I.O. Antitumor and anti-Pneumocystis carinii activities of novel bisbenzamidines. Med. Chem. Res. 2005, 14, 143-157. [CrossRef]

11. Wilson, W.D.; Tanious, F.A.; Mathis, A.; Tevis, D.; Hall, J.E.; Boykin, D.W. Antiparasitic compounds that target DNA. Biochimie 2008, 90, 999-1014. [CrossRef] [PubMed]

12. Chemaxon. Available online: https://www.chemaxon.com (accessed on 18 April 2016). 
13. Schrodinger suite. Available online: http://www.schrodinger.com (accessed on 18 April 2016).

14. Donkor, I.O.; Huang, T.L.; Tao, B.; Rattendi, D.; Lane, S.; Vargas, M.; Goldberg, B.; Bacchi, C. Trypanocidal activity of conformationally restricted pentamidine congeners. J. Med. Chem. 2003, 46, 1041-1048. [CrossRef] [PubMed]

15. Mayence, A.; Vanden Eynde, J.J.; Krogstad, F.M.; Krogstad, D.J.; Cushion, M.T.; Huang, T.L. Parallel solution-phase synthesis of conformationally restricted congeners of pentamidine and evaluation of their antiplasmodial activities. J. Med. Chem. 2004, 47, 2700-2705. [CrossRef] [PubMed]

16. Dykstra, C.C.; McClernon, D.R.; Elwell, L.P.; Tidwell, R.R. Selective inhibition of topoisomerases from Pneumocystis carinii compared with that of topoisomerases from mammalian cells. Antimicrob. Agents Chemother. 1994, 38, 1890-1898. [CrossRef] [PubMed]

17. Henderson, D.; Hurley, L.H. Molecular struggle for transcriptional control. Nat. Med. 1995, 1, 525-527. [CrossRef] [PubMed]

18. Purfield, A.E.; Tidwell, R.R.; Meshnick, S.R. The diamidine DB75 targets the nucleus of Plasmodium falciparum. Malar. J. 2009, 8, 104. [CrossRef] [PubMed]

19. Stead, A.M.; Bray, P.G.; Edwards, I.G.; DeKoning, H.P.; Elford, B.C.; Stocks, P.A.; Ward, S.A. Diamidine compounds: Selective uptake and targeting in Plasmodium falciparum. Mol Pharmacol 2001, 59, 1298-1306. [PubMed]

20. Rodriguez, F.; Rozas, I.; Kaiser, M.; Brun, R.; Nguyen, B.; Wilson, W.D.; Garcia, R.N.; Dardonville, C. New bis(2-aminoimidazoline) and bisguanidine DNA minor groove binders with potent in vivo antitrypanosomal and antiplasmodial activity. J. Med. Chem. 2008, 51, 909-923. [CrossRef] [PubMed]

21. Basselin, M.; Badet-Denisot, M.A.; Lawrence, F.; Robert-Gero, M. Effects of pentamidine on polyamine level and biosynthesis in wild-type, pentamidine-treated, and pentamidine-resistant leishmania. Exp. Parasitol. 1997, 85, 274-282. [CrossRef] [PubMed]

22. Dardonville, C.; Barrett, M.P.; Brun, R.; Kaiser, M.; Tanious, F.; Wilson, W.D. DNA binding affinity of bisguanidine and bis(2-aminoimidazoline) derivatives with in vivo antitrypanosomal activity. J. Med. Chem. 2006, 49, 3748-3752. [CrossRef] [PubMed]

23. Edwards, K.J.; Jenkins, T.C.; Neidle, S. Crystal structure of a pentamidine-oligonucleotide complex: Implications for DNA-binding properties. Biochemistry 1992, 31, 7104-7109. [CrossRef] [PubMed]

24. Mayence, A.; Vanden Eynde, J.J.; Kaiser, M.; Brun, R.; Yarlett, N.; Huang, T.L. Bis(oxyphenylene)benzimidazoles: A novel class of anti-Plasmodium falciparum agents. Bioorg. Med. Chem. 2011, 19, 7493-7500. [CrossRef] [PubMed]

(C) 2016 by the authors; licensee MDPI, Basel, Switzerland. This article is an open access article distributed under the terms and conditions of the Creative Commons Attribution (CC-BY) license (http://creativecommons.org/licenses/by/4.0/). 